UDC 338.47:656.61

JEL L 91, O18, R42

DOI 10.31375/2226-1915-2020-3-91-108

Natalia Grebennyk

$\mathrm{PhD}$ (Economics), Associate Professor,

Department of Entrepreneurship and Tourism, nataly.grebennyk@gmail.com

ORCID ID: https://orcid.org/0000-0002-1554-0697

Yuliia Navrozova

$\mathrm{PhD}$ (Economics), Associate Professor,

Department of Entrepreneurship and Tourism, yuliana docent@hotmail.com

ORCID ID:http://orcid.org/0000-0002-6106-2825

Veronika Shcherbyna

$\mathrm{PhD}$ (Economics), Associate Professor,

Department of Entrepreneurship and Tourism, uktrade14@gmail.com

ORCID ID: https://orcid.org/0000-0002-3917-3617

Odesa National Marine University, Odesa, Ukraine

\title{
PROSPECTS OF INTERACTION OF BUSINESS ENTITIES IN THE MARITIME ECONOMIC COMPLEX OF UKRAINE
}

Abstract. The aim of the research is to assess new forms of interaction between business entities in the maritime economic complex (MEC) of Ukraine. The paper analyses the results of the activities of enterprises of the Ukrainian maritime industry over the years of its independence and noted the growing role of private capital in the development of the MEC.

The share of state enterprises in the port services market is inexorably decreasing, and there are practically no state shipping companies and service enterprises, their market share is minimal, and there is almost no profit. But in the maritime industry, the share of private companies is growing, they are developing, and contribute to increased competition. Therefore, further development of the Ukrainian maritime economic complex is possible with the participation of private companies and with the support of private capital.

The cluster, combining representatives of business, authorities and science, is an informal organization whose main goal is to increase the welfare of the region and the competitiveness of the industry. Clusters are recognized as one of the most efficient production systems in the era of globalization and the knowledge economy, focusing on the priority of their development. A program for clustering the maritime industry and specific steps have been developed to enhance mutually beneficial cooperation in the maritime industry within the framework of the cluster, which will result in increased competitiveness of both coastal regions and the maritime industry as a whole.

Keywords: maritime economic complex, cluster, interaction, program.

$\overline{\text { C) Grebennyk Natalia, Navrozova Yuliia, Shcherbyna Veronika, } 2020}$ 
UDC 338.47:656.61

JEL L 91, O18, R42

DOI 10.31375/2226-1915-2020-3-91-108

\section{ПЕРСПЕКТИВЫ ВЗАИМОДЕЙСТВИЯ СУБЪЕКТОВ ХОЗЯЙСТВОВАНИЯ В МОРЕХОЗЯЙСТВЕННОМ КОМПЛЕКСЕ УКРАИНЫ}

Н.Г. Гребенник

к.э.н., доцент, доцент кафедры «Предпринимательство и туризм» https://orcid.org/0000-0002-1554-0697

Ю.А. Наврозова

к.э.н., доцент, доцент кафедры «Предпринимательство и туризм»

В.В. Щербина

к.э.н., доцент, доцент кафедры «Предпринимательство и туризм» ORCID https://orcid.org/0000-0002-3917-3617

Одесский начиональный морской университет, Одесса, Украина

Аннотация. В статье проанализирована деятельность предприятий в морехозяйственном комплексе (МХК) Украины, оченена роль частного сектора, а также определены перспективы реализачии кластерной кониепичии в МХК Украинь.

Проведенный анализ результатов работы морской отрасли показал, что в период независимости позиции Украины как морской державы были сильно утрачены - уменьши лись объемы морской торговли через порть Украины, снизилась доля государственных портовых операторов в общем грузообороте, сократился совокупный дедвейт торгового флота Украины, его доля в мировых объемах перевозок. Зато в морской отрасли возрастает доля частных компаний, они развиваются, способствуют активизации конкуренции. Поэтому дальнейшее развитие морехозяйственного комплекса Украинь возможно при участии частных компаний и при поддержке частного капитала.

Создание и развитие кластерной модели на морском транспорте может оказаться перспективныл вариантом выхода из сложившегося положения на сегодняшний день в отрасли.

Для скорейшей реализации кластерной концепции в МХК Украины необходимо осуществить следующие шаги:
1) инициировать разработку нормативно-правовой базы по реализации кластерной концепции в Украине;

2) разработать Концепцчию развития МХК Украины,

3) провести публичное обсуждение данной Концепичии;

4) наладить взаимовыгодное сотрудничество между предприятиями и организациями портовой деятельности и учебными заведениями;

5) привлечь к сотрудничеству представителей уже функционирующих в Украине кластеров для обмена опьтом в реализации кластерной концеепции развития.

Реализачия указанных рекомендачий позволит активизировать взаимовыгодное сотрудничество в морской отрасли в рамках кластера, результатом чего будет рост конкурентоспособности как приморских регионов, так и отрасли в иелом.

Ключевые слова: морехозяйственный комплекс, кластер, взаимодействие, программа.

УДК 338.47:656.61

JEL L 91, O18, R42

DOI 10.31375/2226-1915-2020-3-91-108

\section{ПЕРСПЕКТИВИ ВЗАСМОДЇ̈ СУБ'СКТІВ ГОСПОДАРЮВАННЯ \\ В МОРЕГОСПОДАРСЬКОМУ КОМПЛЕКСІ УКРАЇНИ}

Н.Г. Гребенник к.е.н., доцент, доцент кафедри «Підприємництво та туризм» nataly.grebennyk@gmail.com

ORCID ID: https://orcid.org/0000-0002-1554-0697

Ю.О. Наврозова

к.е.н., доцент, доцент кафедри «Підприємництва та туризм» E-mail: Yuliana docent@hotmail.com ORCID ID: http://orcid.org/0000-0002-6106-2825 В.В. Щербина к.е.н., доцент, доцент кафедри «Підприємництво та туризм» uktrade14@gmail.com

ORCID ID: https://orcid.org/0000-0002-3917-3617 Одеський національний морський університет, Одеса, Украӥна

Анотація. У статті проаналізовано діяльність підприємств у морегосподарському комплексі (МГК) України, очінено роль приватного сектора, а також визначені 
перспективи реалізациї кластерної концепції в МГК України.

Проведений аналіз результатів роботи морської галузі показав, щчо в період незалежності позиції України як морської держави були сильно втрачені - зменшилися обсяги морської торгівлі через порти України, знизилася частка державних портових операто- рів в загальному вантажообігу, скоротився сукупний дедвейт торговельного флоту Украӥни, його частка в світових обсягах перевезень. Проте в морській галузі зростає частка приватних компаній, вони розвиваються, сприяють активізачії конкурениії. Тому подальший розвиток морегосподар-ського комплексу Украӥни можливий за участю приватних компаній $і$ за підтримки приватного капіталу. Створення $i$ розвиток кластерної моделі на морському транспорті може виявитися перспективним варіантом виходу із становища на сьогоднішній день в галузі. Для якнайшвидшої реалізації кластерної концеепиії в МГК України необхідно здійснити наступні кроки:

Problem statement. The modern economy of Ukraine is developing in new conditions, when the main factors for the successful development of the country as a whole and the MEC, in particular, are new knowledge, information and innovative technologies, which requires the introduction of new approaches and methods in management.

In modern business conditions, business structures that use new economic approaches in organizing their activities become successful. Such structures most often contain their own research centres, which provide scientific support for their activities, and work closely with educational institutions, within which training and retraining of personnel for the participants of these structures is carried out.

To the fullest extent, the requirements of this interaction are met by such a relatively new form of association
1) ініціювати розробку нормативноправової бази щчодо реалізациї кластерної концепиії в Україні;

2) розробити Концепцію розвитку МГК України;

3) провести публічне обговорення даної Концеепиї̈;

4) налагодити взаємовигідне співробітниитво між підприємствами та організачіями портової діяльності та навчальними закладами;

5) залучити до співпраці представників вже функиіонуючих в Украӥні кластерів для обміну досвідом в реалізації кластерної концепиії розвитку.

Реалізачія зазначених рекомендачій дозволить активізувати взаємовигідне співробітництво в морській галузі в рамках кластера, результатом чого буде зростання конкурентоспроможності як приморських регіонів, так і галузі в иілому.

Ключові слова: морегосподарський комплекс, кластер, взаємодія, програма.

of enterprises and organizations for Ukraine as clusters that have been functioning effectively for a long time not only in industrialized countries, but also in developing economies. Clusters arise at the national, sectoral, regional and municipal levels. The range of forms and types of cluster structures is extremely wide. This creates significant difficulties in the formation of the maritime cluster in a particular region and requires serious research work in this area.

Clusters are recognized as one of the most efficient production systems in the era of globalization and the knowledge economy, focusing on the priority of their development.

When developing strategic plans for the development of the MEC of Ukraine, one should take into account the European experience in the interaction of related sectors of the economy 
of transport and industrial regions. It can become the basis for the creation of a marine cluster in Ukraine with a unified information system, mo-nitoring of goods attraction zones and intersection of traffic flows, calculation of goods efficiency coefficients, the use of freight transport and mechanisms, forecast indicators of added value at each stage production, etc.

In this regard, the issues of improving the interaction system between enterprises and organizations in the MEC of Ukraine through the use of a cluster concept due to its relevance deserve special attention from science. There was a necessity to conduct comprehensive research in order to analyze and evaluate the relevance and feasibility of the relevant transformations and, as a result, develop recommendations for changes in legislative and regulatory acts.

Review of the last research and publications. The theoretical basis of the formation of clusters are devoted to the works of domestic and foreign authors [1-17]. One of the founders of the cluster development theory is the American economist M. Porter [1]. His researches examine in detail the impact of clusters on competitiveness. M. Voynarenko, V. Zakharchenko, V. Osipov, $V$. Geyets and others are engaged in updating the cluster approach for Ukraine [2-4]. The works of V. Chenkalovtsa, N. Grebennik, M. Shevchenko and other scientists are devoted to the problems and prospects of the development of marine clusters [5-10; 14].

Tasks of research. The aim of the research is to assess new forms of interaction between business entities in the MEC of Ukraine. In the article, the tasks have been solved: to analyze the activities of enterprises in the Ukrainian $\mathrm{MEC}$, to assess the role of the private sector, and to identify the prospects for the implementation of the cluster concept in the Ukrainian MEC.

\section{The basic material of the rese-} arch. The future of Ukraine as a maritime power depends on the development of the maritime industry. Today, according to IMO, $90 \%$ of world trade falls on maritime trade. Let's consider how the maritime industry of Ukraine has developed since the period of independence in 1991.

After peak of economic activity in 1990, when 121,4 million tons of cargo were handled, the seaports of Ukraine in 1991 faced a sharp crisis - a decrease in cargo turnover, which was caused by the breakdown in economic ties and a drop in the economy [18]. At that time, the problem finding a new way of development for the enterprises of the maritime economic complex, primarily for ports, became particularly serious. It was during that period that the authorities of the Odessa Commercial Sea Port decided to attract private business for the development of the port industry of Ukraine.

In connection this in 1993 the first private stevedoring companies in Ukraine (such as Ironimpex-Ukraine, Metalz-Ukraine Corp. LTD and Novo$\log$ ) appeared in the Odessa port. The last two stevedores are still working in the port. These were the first joint venture enterprises to which the port assigned storage areas, the infrastructure located on them, and transshipment equipment for the use. For their part, private stevedores guaranteed the attraction of additional freight flows, investment in maintaining the working condi- 
tion of the existing equipment and acquisition of new machinery, as well as modernization of storage areas. Profits resulting from the performance of stevedoring work were divided between the port and the company in accordance with the amount of the investment contribution from each of the parties. A year later, the Transinvestservice (TIS) company, which is now the largest port operator in Ukraine, emerged in the waters of the Yuzhny port. In 1995, the first private trader appeared in the Nikolayev port - CJSC Nikolayev Potash Terminal, subsequently reorganized into the Sea Specialized Port of Nika-Tera [23;24].
The advantages of private port operators are obvious: they have increased transshipment in a short time. In 2019 they handled $78 \%$ of all cargo in Ukrainian ports (fig. 1). Private operators invest in machinery, they have newer cranes, better loading equipment, warehouses. As a rule, salaries in such companies are higher. The involvement of the private sector contributed to the development of the port industry and in 1997, the cargo turnover of the ports of Ukraine began to grow, but only in 2007 the sea trade ports of Ukraine exceeded the level of cargo turnover compared to 1990 for the first time: 123,7 million tons compared to 121,4 million tons in 1990 (fig. 1).

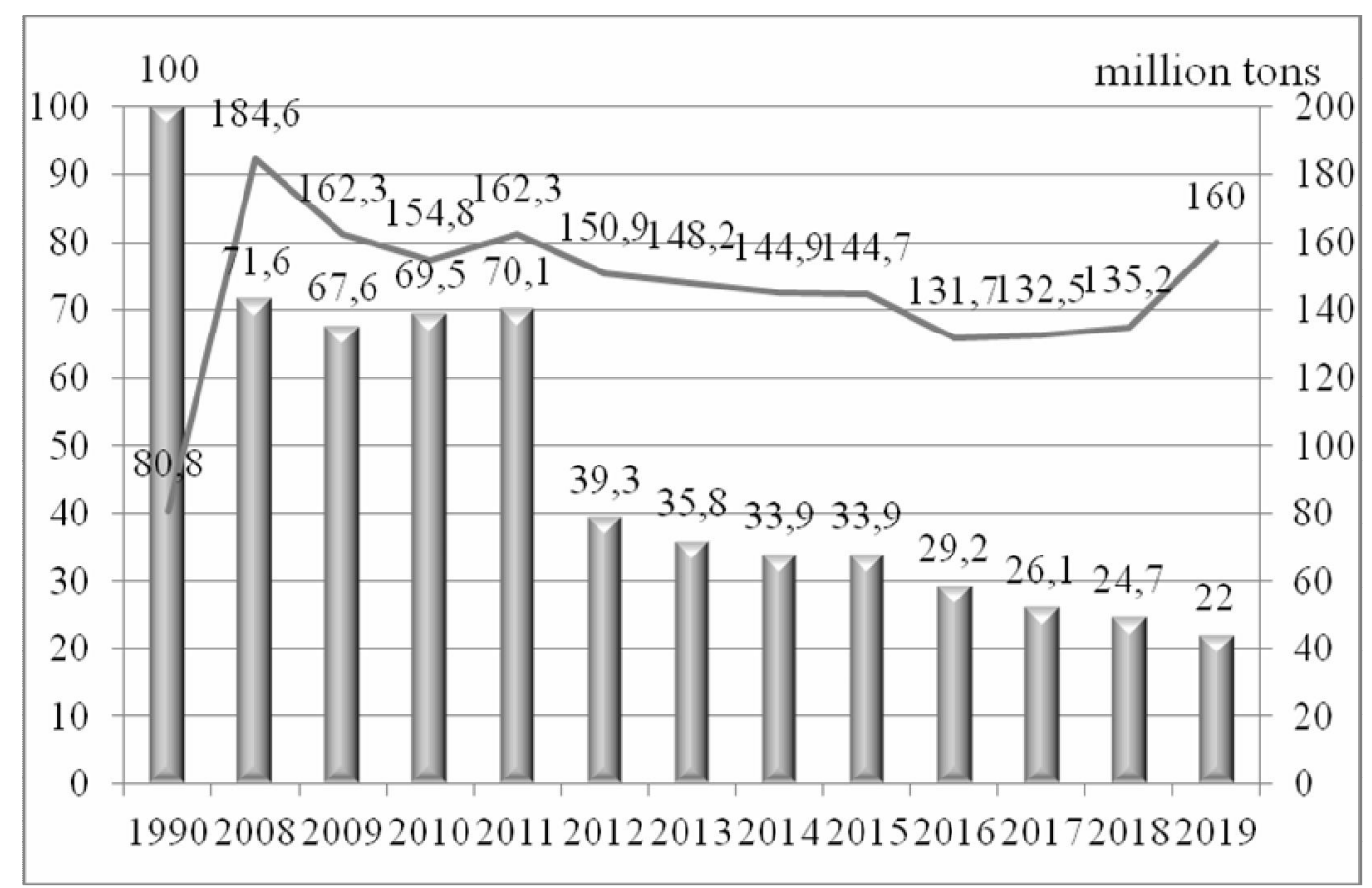

Fig. 1. Cargo turnover in Ukraine (million tons)

and change part of state private port operators (\%)

Source: [18-20] 
If we consider the shipping industry, the most striking and, at the same time, the most tragic event of the first years of independence of Ukraine was the loss of the Black Sea Shipping Company (BSSC) and its bankruptcy. In 1991, 234 vessels were listed on the BSSC's balance. Due to corrupt management actions, the company's fleet by January 1997 had been reduced to 15 vessels. The remaining vessels were illegally sold offshore or cut into scrap metal. In 2006, the government began a reorganization process. However, it did not bring results, in 2013 the size of the fleet was reduced to one ship [19].

Back in 2004, Ukraine was one of the 35 largest countriesshipowner with a total deadweight of vessels under the national flag of more than 1,7 million tons. And in 2007, the deadweight of the fleet under the Ukrainian flag was reduced to 383,6 thousand tons. In 2018 the deadweight of the merchant fleet of Ukraine amounted to 500 thousand tons, mainly small-tonnage vessels with a carrying capacity of up to 1,500 ton, their number is 1,501 vessels, including maritime vessels and inland navigation: cargo, passenger, service and auxiliary ones under the Ukrainian flag [20].

Statistics show that $7 \%$ of merchant ships are older than 50 years, and some are even older than 60 years (fig. 2).

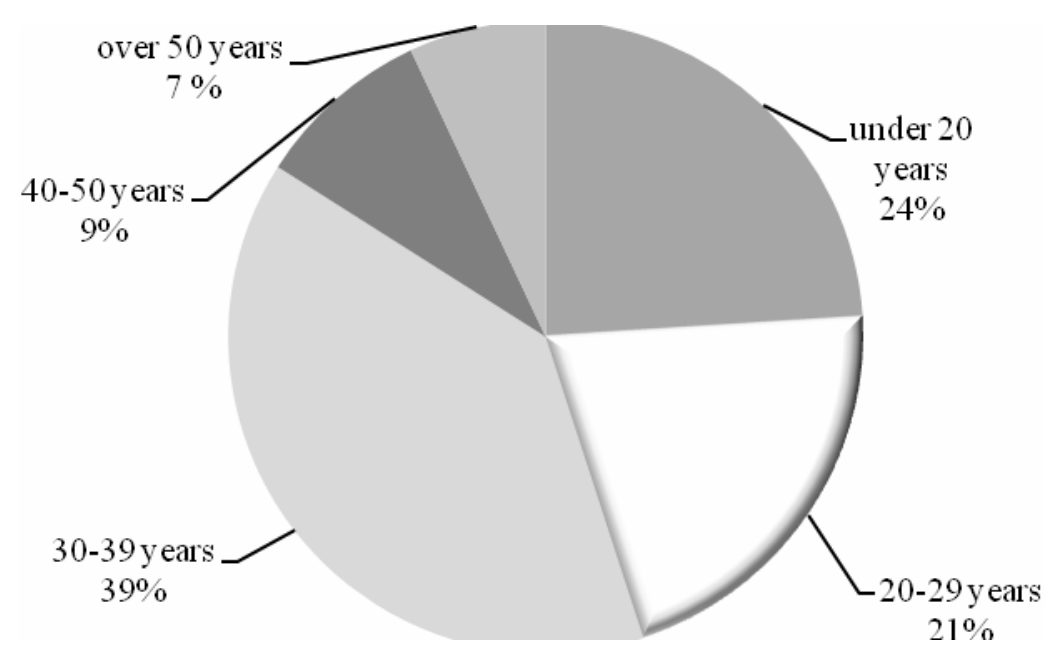

Fig. 2. Fleet structure under the flag of Ukraine, 2018

Source: [22; 23]

Ships between the ages of 40 and 50 make up $9 \%$ of the total number of ships. The largest segment is occupied by vessels aged 30-39 years, which is $39 \%$ of the total number of vessels, vessels under the age of 20 years make 
up $24 \%$. The young Ukrainian fleet accounts for only $24 \%$ of the total number of vessels, however, this entire fleet is small-tonnage and belongs to private companies [22]. The largest shipowners of the Ukrainian fleet are JSSC «Ukrrichflot», LLC «Nibulon» and PJSC «Ukrainian-Danube Shipping Company» (fig. 3). These shipowners own more than $50 \%$ of the entire merchant fleet under the national flag of Ukraine. Another 8-10\% of the merchant fleet is managed by commercial sea ports (Mariupol, Odessa, Nikolayev, etc.). There are a lot of small shipowners, who own 3-6 vessels aged 35 years and older. Their market share is approximately $2-4 \%[22 ; 23]$.

In 2019, there were two state shipping companies left - PJSC «Ukrainian-
Danube Shipping Company» and «State Shipping Company Ukrtanker», whose profit in 2018 amounted to $0 \mathrm{UAH}$ [19].

Since 1995, Ukraine has seen not only the decline in the fleet and its carrying capacity, but also the fall in the volume of traffic by the national fleet (fig. 4).

After Ukraine gained independence in 1991, service enterprises (such as forwarding, agent, crewing companies, freight and customs brokers, etc.) became the first private companies in the maritime industry. Nowadays, several thousand private service companies operate in sea transport, many of which are representative offices of foreign companies.

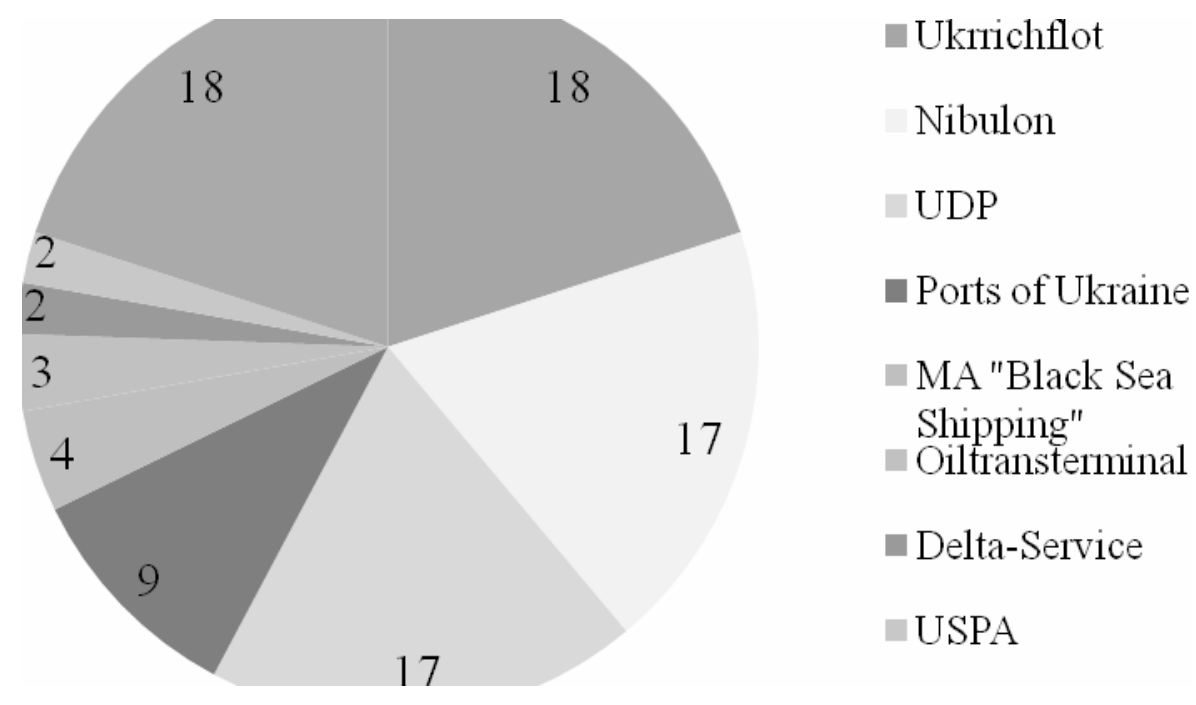

Fig. 3. Structure of Ukrainian shipowners fleet, 2018

Source: [23] 


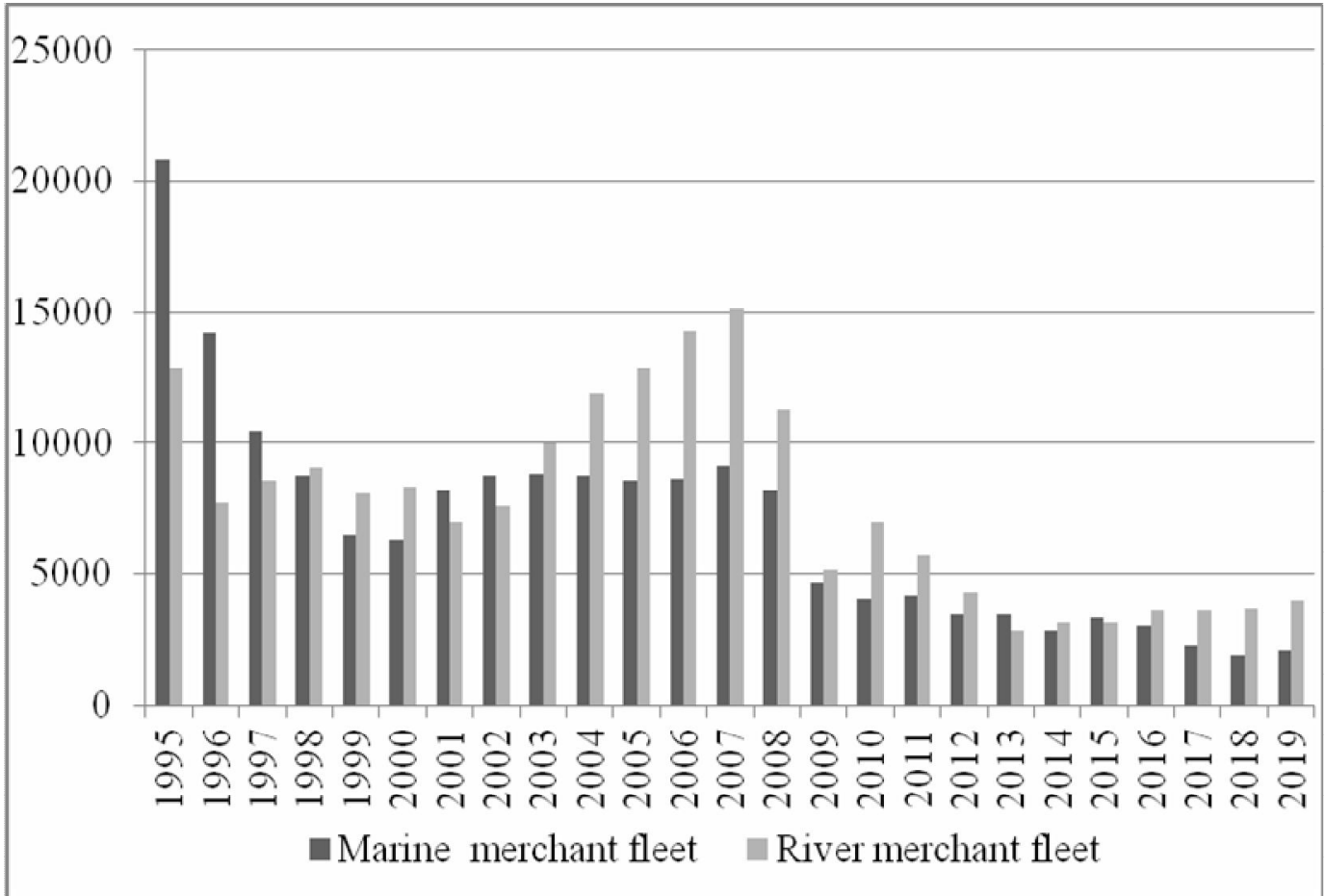

Fig. 4. Volume of transported goods by the Ukrainian marine and river merchant fleet, thousand tons

Source: [25]

The only state-owned enterprise that provides agency and forwarding services to foreign and Ukrainian shipowners and cargo owners in the Black Sea ports of Ukraine, competing with more than 300 private agent and forwarding companies, is the state-owned enterprise Black Sea General Shipping Agency INFLOT, founded in 1934 [19].

The rating of the largest service enterprises is presented in Table 1, all enterprises included in the rating are private.

The analysis of the maritime industry performance has shown that during the period of independence, Ukraine's position as a maritime power was greatly lost - the volume of sea trade through the ports of Ukraine decreased, the share of state port operators in the total cargo turnover decreased, the total deadweight of the Ukrainian merchant fleet decreased, its share in the world's freight traffic. The share of state enterprises in the port services market is inexorably decreasing, and there are practically no state shipping companies and service enterprises, their market share is minimal, and there is almost no profit. But in the maritime industry, the share of private companies is growing, they are developing, and contribute to increased competition. 
DEVELOPMENT OF MANAGEMENT AND ENTREPRENEURSHIP METHODS ON TRANSPORT, № 3 (72), 2020
РОЗВИТОК МЕТОДІВ

УПРАВЛІННЯ ТА ГОСПОДАРЮВАННЯ

НА ТРАНСПОРТІ, № 3 (72), 2020

Table 1

Top freight forwarding and agency companies in 2019 years

\begin{tabular}{|c|c|c|}
\hline \multicolumn{3}{|c|}{ Top 5 non-containerized cargo freight forwarding companies } \\
\hline № & Companies & \\
\hline 1 & Metinvest-Shipping & 32,86 \\
\hline 2 & SMT LTD & 11,81 \\
\hline 3 & Nika Trans Logistika & 8,67 \\
\hline 4 & ATIS & 7,18 \\
\hline 5 & Portinvest Logistic & 5,95 \\
\hline \multicolumn{3}{|c|}{ Top 5containerized cargo freight forwarding companies } \\
\hline № & Companies & pieces \\
\hline 1 & «Global ocean link» & 32800 \\
\hline 2 & «Iteris» & 18242 \\
\hline 3 & «Lukro» & 16230 \\
\hline 4 & «Arena Marine» & 16051 \\
\hline 5 & Group «Uni Lamann Group» & 13842 \\
\hline \multicolumn{3}{|c|}{ Top 5 agency companies } \\
\hline № & Companies & ships \\
\hline 1 & Metinvest-Shipping & 1094 \\
\hline 2 & Stark Shipping & 790 \\
\hline 3 & Atis & 528 \\
\hline 4 & Portinvest Logistic & 395 \\
\hline 5 & Nika Trans Logistika & 330 \\
\hline
\end{tabular}

Source:[19]

Therefore, further development of the Ukrainian maritime economic complex is possible with the participation of private companies and with the support of private capital.

The cluster, combining representatives of business, authorities and science, is an informal organization whose main goal is to increase the welfare of the region and the competitiveness of the industry.

The most famous global cluster organization in maritime transport is the European Network of Maritime Clusters (ENMC). It includes maritime cluster organizations of such countries as
Belgium, Denmark, Finland, France, Germany, Italy, the Netherlands, Norway, Poland, Spain, Sweden, Great Britain and Bulgaria [11].

ENMC was founded on November 4, 2005 in Paris. Its goal was to exchange experiences, learn from each other, coordinate activities, as well as develop and strengthen the maritime clusters of the Member States and Europe as a whole.

ENMC is a flexible organization, whose members on a voluntary basis cooperate in resolving issues related to their activities. Thus ENMC helps to increase the chances of attracting the 
attention of the authorities to solving problems that are common to maritime enterprises of all countries.

In January 2006 in Bergen (Norway) at the seminar «Europe of the Sea» much attention was paid to the peculiarities of creating and functioning of maritime clusters. It was indicated that a maritime cluster means a group of firms, research institutes and educational organizations (universities, specialized schools, etc.), sometimes they enjoy the support of national or local authorities, collaborating to introduce technical innovations to improve the performance of the maritime industry [6].

In some European countries (Holland, Norway, Italy), maritime clusters are understood as a complex of maritime activities that are intertwined and interact, for example, shipping, port operation, shipbuilding and ship repair, fishing, maritime tourism, offshore enterprises, etc.

A maritime cluster can be created and function according to various schemes [13; 14], Germany;

1) «top-down» - this was done in

2) «bottom-up» - the principle of the cluster performance in Norway;

3) «combination play» (a combination of the above schemes) - the Dutch maritime network was built according to this scheme.

In the case of the top-down marine cluster creation, the initiative comes from the government and in the future, the marine cluster receives significant support from the authorities. In the work of such clusters, the emphasis is on long-term national projects mainly of a social orientation.
When creating a marine cluster according to the bottom-up scheme, the initiative comes from large leading companies, or from industry associa-tions. The operation of such marine clusters focuses on short-term business development issues.

According to the scheme, which provides for the combination play, the marine cluster is created by the joint efforts of the authorities and the private sector and provides for the active use of various forms of public-private partnership. The functioning of these marine clusters combines the various characteristics of the above schemes, and is the most promising for Ukraine.

In different countries, special institutions, in particular centers of expertise (in Finland), centers of excellence (Holland, USA), centers for marketing and analytical research (USA, Kazakhstan), business centers, technology parks, technopolises, special economic zones, etc. perform development, construction of network structures and their internationalization.

The sources of resource support for the implementation of cluster policies in different countries include:

- regional target and departmental programs;

- government programs; funds;

- state development institutions

- venture capital funds;

- funds for the implementation of small business development programs and alike.

It should be highlighted that in all countries the emphasis is on the need for appropriate state policy in the field of clustering. For example, Singaporean experience shows that public policy is 
crucial in the process of cluster formation and development. The necessary conditions for the successful organization of such clusters are the coordinated and focused activities of all government departments, as well as a stable long-term state economic policy in the investment, tax and innovation spheres.

The process of creating maritime cluster organizations continues, and most countries have several cluster structures operating in the maritime industry and combining various spheres (sectors) of activity. These spheres are combined into three groups $[13 ; 15]$ :

1) traditional maritime spheres;

2) coastal and maritime recreation and tourism;

3) fishing.

In Ukraine, there are necessary conditions for the creation and effective functioning of the maritime cluster, which were classified as facilitating and inhibiting (Fig. 5) and a model of the maritime cluster was proposed with a description of the list of its participants [5].

In 2008, the Ukrainian Cabinet of Ministers submitted the Draft «Concepts for Creating Clusters in Ukraine», which contained an analysis of the use of the cluster system in the world, indicated the reasons for its insufficient use in Ukraine and substantiated recommendations for the spread of clustering in the country's economy [5].

The above-mentioned Project indicated that the low level of cluster distribution in Ukraine is due primarily to the lack of scientific development and legal support for the functioning of this system. However, this document remained a draft and no further actions regarding the use of a cluster concept in the regulatory field of Ukraine were observed.

There is an understanding of the importance of clustering on the part of power structures in the maritime industry of Ukraine. In particular, the Draft «Strategy for the Development of Ukrainian Seaports» proposes a map of the ports specialization, which are the basis for the strategy. This document identifies 3 types of strategic development:

- efficient cargo handling;

- harmonious growth;

- creation of clusters.

It is indicated that, in accordance with the Draft Strategy, it is advisable to form 4 clusters: grain and oil in the region of Odessa and Nikolayev, chemistry in the South, containers in the region of Odessa.

In order to identify the reserves for using the potential of the cluster concept in the MEC of Ukraine and to determine the directions on how to maximize the use of the potential of the maritime cluster in the region of the North-West Black Sea coast, a survey was carried out. As a result, according to experts, the most important factor affecting the development of clusters was determined as «the level of professionalism of managers in the industry». The factor «system of training qualified specialists» was recognized as the second most important. The third position is occupied by the factor «level of scientific research in the industry and the degree of their practical implementation» [7]. 

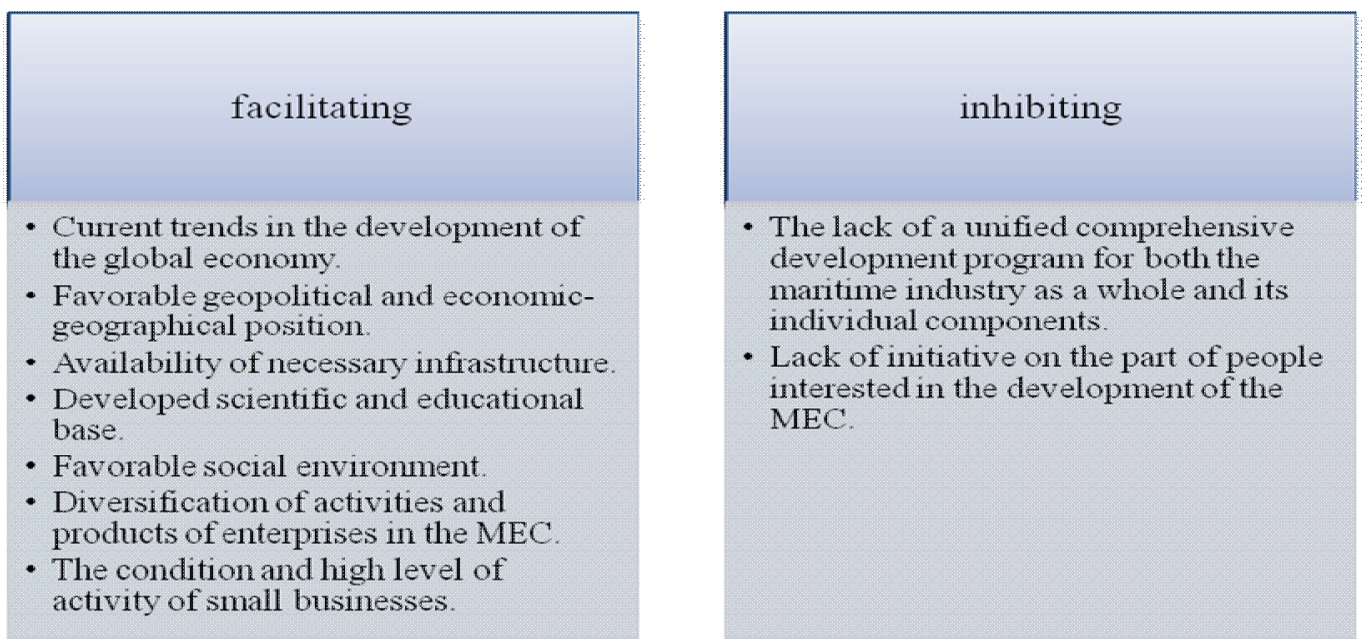

Fig. 5. Conditions for the creation of the maritime cluster

\section{Source: [5]}

The study showed that two components of the maritime cluster - science and business are fully present and are used at a fairly high level in the Odessa region. Power structures are also available to ensure the proper functioning of the cluster.

However, the organization of the main components of the maritime cluster significantly reduces its functioning effectiveness.

For the effective implementation of the cluster concept in the maritime industry of Ukraine, a clustering program is proposed, the content of which is shown in Figure 6.

For the rapid implementation of the cluster concept in the MHC of Ukraine, the following stages must be undertaken:

1) conduct a research in order to identify the basis of the clusters functioning in Ukraine and the features of their implementation in the maritime industry, based on what to initiate the development of proposals for the development of a regulatory framework for the implementation of the cluster concept in Ukraine;

2) establish a Concept for the development of the MHC of Ukraine using advanced forms of interaction between business entities, based on the territorial-sectoral construction principle, which means that it is essential to provide such a program of use and a mechanism for implementing the cluster development notion of the marine industry in the case of this Concept;

3) hold a public discussion of this Concept with the involvement of both scientists, specializing on the maritime industry, and representatives of enterprises and port activity organizations and local authorities. 


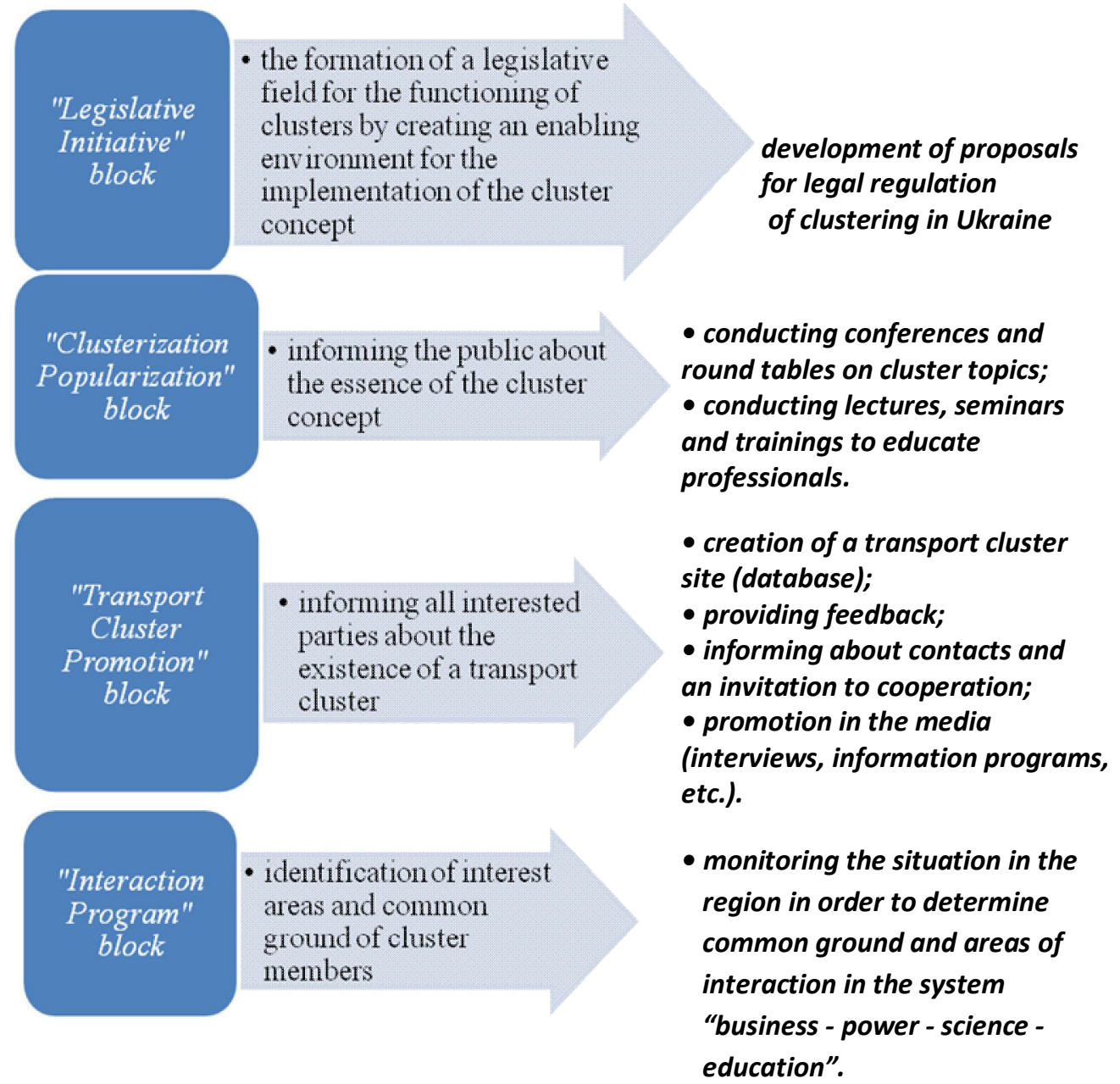

Fig. 6. Content of the Maritime Clustering Program

Source: [17]

This must be done for several reasons:

- the implementation of any concept is either impossible or is going to be fraught with significant difficulties without their active participation;

- the fact is known that innovations that are initiated by direct market participants, and are a reaction to market needs, have a higher percentage of suc- cessful implementation than innovations imposed by administrative methods;

4) establish mutually beneficial cooperation between enterprises and port activity organizations and educational institutions, which can be expressed in the following forms:

- systematic information of universities from port enterprises about their needs for experts in certain lines with a possible narrow specialization in 
particular areas of management: maritime business, port management, port marketing, logistics, financial management, crisis management, etc.;

- attraction of students and graduates to internships with their possible subsequent employment;

- Conducting conferences, forums, round table discussions and scientific seminars with the participation of enterprise representatives and port activity organizations as well as the university faculty members in order to identify common problems and joint development of methods for their solution;

5) involve representatives of clusters already functioning in Ukraine for cooperation to exchange experience in implementing the cluster development concept.

The implementation of these recommendations will enhance mutually beneficial cooperation in the maritime industry within the framework of the cluster, which will result in increased competitiveness of both coastal regions and the industry as a whole.
Conclusions. During the thirty years of Ukraine's independence, maritime positions were seriously lost, which manifested itself in a decrease in the cargo turnover of Ukrainian seaports, the total deadweight of the Ukrainian merchant fleet and its share in world traffic. At the same time, the role of private companies in all sectors of the MEC is growing. Therefore, further development of the Ukrainian MEC is possible with the participation of private companies and with the support of private capital.

The study showed that in the Odessa region, two components of the maritime cluster - science and business - mare fully present and used at a fairly high level. For the effective implementation of the cluster concept in the maritime industry of Ukraine, the Maritime Clustering Program is proposed, which will intensify mutually beneficial cooperation in the maritime industry within the cluster, which will increase the competitiveness of coastal regions and the maritime industry.

\section{СПИСОК ЛІТЕРАТУРИ}

1. Портер М. Конкуренция. Пер. с англ.: М.: Издательский дом «Вильямс», 2005. $608 \mathrm{c}$.

2. Войнаренко М.П. Кластери як иентри економічного зростання регіонів за умов кризи // Развитие инновачионных кластеров в современных условиях реструктуризачии экономики: материаль IV Междунар. Науч.-практ. конф., 1-2 июня 2009 г. Севастополь: ТПП, 2009. С. 16-29.

3. Геєць В.М. Кластери і мережеві структури в економіці - тема досить иікава, але на сьогодні ще не до кіния вивчена // Економіст. 2008. № 10. C. 10-11.

4. Захарченко В.И., Осипов В.И. Кластерная форма территориальнопроизводственной организачии: Ч.2. Повышение региональной конкурентоспособности на основе кластерного подхода. Одесса: «Фаворит»«Печатный дом», 2010. 236 с. 
5. Чекаловеи В.И., Гребенник Н.Г. Предпосылки использования кластерной концепции в портовом хозяйстве Украины // Транспорт. 2009. № 20 (552). C. 57-62.

6. Шевченко М. Конщепџия морских кластеров // Порты Украины. 2006. № 6. C. $55-56$

7. Крыжсановский С.В. Морские торговые порты Украины в рыночных условиях: Монография. Одесса: Астропринт, 2008. 184 c.

8. Гребенник Н.Г. Основы оценки эффрективности функционирования морского кластера // Вісник економіки транспорту і промисловості. № 30, 2010, C. 259-260

9. Александров В.Л. Проблемы и перспективы создания кластера морской индустрии в Санкт-Петербурге. URL: http://spp.spb.ru/ru/node/3802.

10. Бабурина О.Н., Мезенцев А. В. Морские кластеры: понятие, составляюшие и драйверы развития // ХІІІ региональная научно - техническая конференция ГМУ имени адмирала Ф.Ф. Ушакова. URL:https://www. researchgate.net/publication/318530725_Maritime_Clusters_Concept_Compo nents_and_Development_drivers_Morskie_klastery_ponatie_sostavlausie_i_dr ajvery_razvitia

11. European Network of Maritime Clusters. (2015). URL: http://www.europeannetwork-of-maritime-clusters.eu [in English]

12. The Danish Maritime Cluster - an Agenda for Growth; Ministry of Economic and Business Affairs. Copenhagen, Denmark, 2006. p. 32.

13. The role of Maritime Clusters to enhance the strength and development in European Network of Maritime Clusters. URL: http://www.europeannetwork-of-maritime-clusters.eu/ (дата обращения: 8.05.2020 г.)

14. Tamara Blonk. Mapping the European maritime cluster. Netherlands Maritime Technology November 2015, Rotterdam

15. Balance. Competitive position and future opportunities of the European Maritime Supplies Industry. Bremen: 2014, European Commission.

16. Проект розпорядження Кабінету Міністрів Украӥни «Про концепцію створення кластерів в Україні». URL: http://www.rada.gov.ua

17. Вороной В.И., Гребенник Н.Г., Наврозова Ю.А. Програма кластеризаиії в портовій діяльності Украӥни //Розвиток методів управління та господарювання на транспорті. 2013. Вип. 2. С. 16-27.

18. Подбельиева Е.В. Эколого-географические особенности потенциила морских портов Украины // Екологічна безпека прибережної та шельфової зон та комплексне використання ресурсів шельфу: 3б. наук. праџь. Севастополь, 2005. Bun. 12. C. 286-293. URL: http://dspace.nbuv.gov.ua/handle/ $123456789 / 57013$

19. Частная перевалка. URL: https://biz.censor.net.ua/r3018058

20. Эксплуатационная деятельность. URL: http://www.port.odessa.ua/ru/ istoriyalekspluatatsionnaya-deyatelnost 
21. 25 знаковых событий транспортной отрасли за 25 лет независимости Украины. URL: https://cfts.org.ua/spetsproekty/25_znakovykh_ sobytiy_ transportnoy_otrasli_za_25_let_nezavisimosti_ukrainy

22. Павловская Л.А., Петриченко Л.В. Проблемы речного судоходства в Украине // Розвиток методів управління та господарювання на транспорті, 2018.3 (64). C. 94-106.

23. Регістрова книга суден України URL: http://shipregister.ua/pdf/reg-ships.pdf

24. Офіџійний сайт Адміністрації морських портів України. URL: http://www.uspa.gov.ua

25. Данные Госкомстата Украины. URL: http://www.ukrstat.gov.ua/operativ/ operativ old/tz/prtk/2000.html

\section{REFERENCES}

1. Porter, $M$ (2005). Konkurentsiya [Competition]. Per. S angl. M.: Izdatelskiy dom «Vilyams»,. 608 [in Russian]

2. Vojnarenko, M.P. (2009). Klastery' yak centry' ekonomichnogo zrostannya regioniv za umov kry 'zy ' [Clusters as centers of economic growth of regions during the crisis]. Razvitie innovatsionnyih klasterov $v$ sovremennyih usloviyah restrukturizatsii ekonomiki - Development of innovative clusters in modern conditions of economic restructuring: materials. Sevastopol: TPP, P. 16-29 [in Russian].

3. Geyecz' V.M. (2008). Klastery` i merezhevi struktury` v ekonomici - tema dosy 't' cikava, ale na s'ogodni shhe ne do kincya vy vchena [Clusters and network structures in the economy - a topic quite interesting, but not yet fully understood]. Ekonomist-Economist. \# 10. P. 10-11 [in Ukrainian].

4. Zaharchenko, V.I. \& Osipov, V.I. (2010). Klasternaya forma territorialnoproizvodstvennoy organizatsii: Ch.2. Povyishenie regionalnoy konkurentosposobnosti na osnove klasternogo podhoda [The cluster form of the territorial production organization: Part 2. Improving regional competitiveness based on the cluster approach]. Odessa: «Favorit» - «Pechatnyiy dom», 236 [in Russian].

5. Chekalovets, V.I. \& Grebennik, N.G. (2009). Predposyilki ispolzovaniya klasternoy kontseptsii v portovom hozyaystve Ukrainyi [Preconditions for the use of the cluster concept in the port economy of Ukraine]. Transport Transport. \# 20 (552). P. 57-62 [in Russian].

6. Shevchenko, M. (2006). Kontseptsiya morskih klasterov [The concept of sea clusters]. Portyi Ukrainyi-Ports of Ukraine. \# 6. P. 55-56 [in Russian].

7. Kryizhanovskiy, S.V. (2008).Morskie torgovyie portyi Ukrainyi v ryinochnyih usloviyah [Sea trade ports of Ukraine in market conditions]: Monografiya. Odessa: Astroprint, 184 [in Russian]. 
8. Grebennik, N.G. (2010). Osnovyi otsenki effektivnosti funktsionirovaniya morskogo klastera [Basics for assessing the effectiveness of the functioning of the maritime cluster] // Visny`k ekonomiky transportu i promy`slovosti Bulletin of the economy of transport and industry. No. 30, pp. 259-260 [in Russian].

9. Aleksandrov, V.L. (2006). Problemyi i perspektivyi sozdaniya klastera morskoy industrii v Sankt-Peterburge [Problems and prospects of creating a cluster of the maritime industry in St. Petersburg]. Retrieved from http://spp.spb.ru/ ru/node/3802 [in Russian].

10. Baburina, O.N. \& Mezentsev, A.V. Morskie klasteryi: ponyatie, sostavlyayuschie i drayveryi razvitiya [Marine clusters: concept, components and drivers of development]. XIII regionalnaya nauchno - tehnicheskaya konferentsiya GMU imeni admirala F.F. Ushakova - XIII Regional Scientific and Technical Conference of the State Medical University named after Admiral F.F. Ushakov. Retrieved from Https://www.researchgate.net/publication/318530725_Maritime_Clusters_Concept_Components_and_Development_drivers_Morskie_klast ery_ponatie_sostavlausie_i_drajvery_razvitia [in Russian].

11. European Network of Maritime Clusters (2015). Retrieved from http:// www.european-network-of-maritime-clusters.eu

12. The Danish Maritime Cluster - an Agenda for Growth; Ministry of Economic and Business Affairs. Copenhagen, Denmark, 2006. p. 32.

13. The role of Maritime Clusters to enhance the strength and development of maritime sectors. Retrieved from http://ec.europa.eu/maritimeaffairs/pdf/clusters/workshop presentation thijssens_en.pdf

14. Tamara Blonk (2015). Mapping the European maritime cluster. Netherlands Maritime Technology November, Rotterdam

15. Balance. Competitive position and future opportunities of the European Maritime Supplies Industry. (2014). Bremen: European Commission.

16. Proekt rozporyadzhennya Kabinetu Ministriv Ukraïni «Pro kontseptsiyu stvorennya klasteriv v Ukraïi». [Draft order of the Cabinet of Ministers of Ukraine "On the concept of creating clusters in Ukraine»] (2008). available at: http://www.rada.gov.ua. [in Ukrainian].

17. Voronoy, V.I., Grebennik, N.G. \& Navrozova, Yu.A. (2013). Programa klasterizatsiï $v$ portoviy diyalnosti Ukraïni [Program activities in the port clustering Ukraine]. Rozvitok metodiv upravlinnya ta gospodaryuvannya na transporti - Development of methods of management and entrepreneurship of transport, 2. 16-27. [in Ukrainian].

18. Podbelceva, E.V. (2005). Ekologo-geograficheskie osobennosti potenciala morskih portov Ukrainy [Ecological and geographical features of the Ukrainian seaports potential] // Ekologichna bezpeka priberezhnoyi ta shelfovoyi zon ta kompleksne vikoristannya resursiv shelfu: $Z$ b. nauk. pr. Sevastopol $12 . \quad P$. 286-293. Retrieved from http://dspace.nbuv.gov.ua/handle/ 123456789/57013, accessed 20 June 2020. 
19. Chastnaya perevalka [Private transshipment] (2017). Business Cenzor Retrieved from https://biz.censor.net.ua/r3018058, accessed 20 June 2020.

20. Ekspluatacionnaya deyatelnost [Operational activity]. Odessa Sea Port Authority. Retrieved from http://www.port.odessa.ua/ru/istoriya/ekspluatatsionnayadeyatelnost, accessed 20 June 2020.

21. 25 znakovyh sobytij transportnoj otrasli za 25 let nezavisimosti Ukrainy [25 significant events of the transport industry for 25 years of independence of Ukraine] (2017). Centre for transport strategies. Retrieved from https:// cfts.org.ua/spetsproekty/25_znakovykh_sobytiy_transportnoy_otrasli_za_25_le $t$ nezavisimosti_ukrainy, accessed 20 June 2020 [in Russian].

22. Pavlovskaya, L.A. \& Petrichenko, L.V. (2018). Problemi rechnogo sudohodstva $v$ Ukraine [The problem of river navigation in Ukraine] // Rozvitok metodiv upravlinnya ta gospodaryuvannya na transporti - Development of methods of management and entrepreneurship of transport. 3 (64). P. 94-106. Retrieved from https://doi.org/10.31375/2226-1915-2018-3-94-106, accessed 20 June 2020 [in Russian]

23. Register book of ships of Ukraine. Retrieved from http://shipregister.ua/pdf/ reg-ships.pdf, accessed 20 June 2020.

24. Official site of Ukrainian Port State Authority. Retrieved from http://www. uspa.gov.ual, accessed 20 June 2020.

25. Data of the State Statistics Committee of Ukraine. Retrieved from http://www.ukrstat.gov.ua/operativ/operativ_old/tz/prtk/2000.html, accessed 20 June 2020.

Стаття надійшла до редакиії 19.09.2020

Посилання на статтю: Гребенник Н.Г., Наврозова Ю.О., Щербина В.В. Перспективи взаємодії суб'єктів господарювання в морегосподарському комплексі України // Розвиток методів управління та господарювання на транспорті: Зб. наук. праць, 2020. № 3 (72). С. 91-108. DOI 10.31375/2226-1915-2020-3-91-108.

Article received 19.09.2020

Reference a JournalArtic: Grebennyk, Natalia, Navrozova, Yuliia \& Shcherbyna,Veronika (2020). Prospects of interaction of business entities in the maritime economic complex of Ukraine. Development of management and entrepreneurship methods on transport, 3 (72), 91-108. DOI 10.31375/2226-1915-2020-3-91-108. 